\title{
Biology of Lasioseius aegypticus Afifi (Mesostigmata: Ascidae) \\ Fed on the Two Astigmatid Mites, Rhizoglyphus echinopus, Acarus siro and the Fungus Aspergillus niger at Two Temperature Degrees
}

\author{
M. M. El-Sebaay \\ Plant Protection Research Institute, A.R.C., Dokki, Giza, Egypt.
}

\begin{abstract}
The developmental time and fecundity of Lasioseius aegypticus were investigated at 25 and $35^{\circ} \mathrm{C}$ and $75 \%$ R.H. when fed on the astigmatid mites, (Rhizoglyphus echinopus and Acarus siro) and the fungus Aspergillus niger. The incubation period, life cycle, adult longevity and life span and female fecundity of L. aegypticus significantly differed according to the different conditions (diets and temperatures). The longest incubation period was noticed when the females of $L$. aegypticus fed on $R$. echinopus at $25^{\circ} \mathrm{C}$ ( 2.2 days); while the shortest period was for male on R. echinopus at $35^{\circ} \mathrm{C}(1.57$ days). Life cycle was longer when females reared on $R$. echinopus at $25^{\circ} \mathrm{C}$, as durated 8.5 days; while the shortest period was for males (62 days) on A. siro at $35^{\circ} \mathrm{C}$. The mean longevity of L. aegypticus female fed on R. ehinopus at $25^{\circ} \mathrm{C}$ lasted the longest period (17.4 days); while the shortest was 8.18 days on $A$. niger at $35^{\circ} \mathrm{C}$. The female fecundity was affected by diet and temperature, as it was high when mites fed on $R$. echinopus at 35 and $25^{\circ} \mathrm{C}$ ( 24.5 and 22.2 eggs, respectively) and ( 24.5 $\& 20.1$ eggs on $A$. siro) and (20.5 \& 17.6 eggs) on A. niger, respectively.
\end{abstract}

Key words: Acarus siro, Biology, Fungus, Lasioseius aegypticus, Rhizoglyphus echinopus, Temperature.

\section{INTRODUCTION}

Members of the family Ascidae comprise large groups of free-living mites, Evans (1961). Some species are fungivorous; while others are probably pollen feeders or predators on young saprophytic mites, insects and nematodes. Mites of the genus Lasioseius Berlese seem to have a world-wide distribution; and representatives have been found in every continent except Antarctica. Some species of this genus inhabit the nests and shelters of birds, mammals and other arthropods where they probably feed on fungi and saprophytic arthropods; while other species occur in soil and humus and on plants where they prey on other invertebrates or feed on fungi and pollen (Evans and Sheals, 1959). The present work aimed to shed some lights on the biological aspects of the mesostigmatid mite, Lasioseius aegypticus Afifi (Ascidae) on three stored product pests, the two acarids Rhizoglyphus echinopus and Acarus siro and the fungus Aspergillus niger. They infested onion bulbs at different laboratory conditions.

\section{MATERIALS AND METHODS}

\section{Isolation of Lasioseius aegypticus:}

Samples of about 10 onion bulbs (randomizedly collected) were taken from onion bulbs stored in the open field and covered with wheat straw; at Quiesna region, El-Menofia Governorate. Mite individuals of L. aegypticus were isolated by using modified Tullgern funnel in Acarology Dept. Plant Protection Research Institute, A.R.C.

\section{Rearing units of L. aegypticus:}

The plastic rearing units were constructed for mass rearing the isolated mite $L$. aegypticus, each plastic unit was $(1.5 \mathrm{~cm}$. in diameter and $2.0 \mathrm{~cm}$. height). The bottom covered with a layer of a plaster of Paris and charcoal mixture. This bottom was kept moist, and relative humidity was maintained by adding one or two drops of water every two days. A camel hairbrush was used to transfer the mites to the cages. Observations of biological aspects (incubation period, life cycle, longevity, fecundity and hatchability \%) were made twice a day. The plastic rearing cages were prepared in a way that they could be handled with a minimum of disturbance to the mites. They were stocked in trays or holders placed in carton boxes $(20 \times 15 \times 8 \mathrm{~cm})$.

\section{The diets preparing:}

The species of Rhizoglyphus echinopus (A) and Acarus siro (B) were obtained from the same mentioned onion bulbs and reared on powder of yeast at the Acarology Dept., Plant Protection Res. Inst. For obtaining pure culture, adults of identified species were placed in rearing chamber $(4 \times 4 \times 3 \mathrm{~cm}$.) and covered with soft plastic cover containing some pores for air. Dry yeast granules were added as exchange food and a few drops of water were added as a source of humidity. By using a camel brush, the motile stages of acarid mites were put in rearinge cells of the tested predaceous mites. The pure culture of the fungus Aspergillus niger (C) was already obtained from Plant Pathology Research Institute; A.R.C. The experiments were conducted at 25 and $35 \pm 2{ }^{\circ} \mathrm{C}$ and $75+5 \%$ R.H.

\section{RESULTS AND DISCUSSION}

\section{Habitat and behavior:}

L. aegypticusis very active mite which moves here and there; searching for their prey individuals. 
Members of this species preferred moderate humidity and rearing cages had to be supplied frequently with water droplets and the females of these tested mites preferred to deposit their eggs solitary.

\section{Hatching:}

Eggs are whitish in color, and then become creamy before hatching. Hatching occurs through a longitudinal median slit.

\section{Molting:}

Immatures of this species when full grown entered a semiquiescent period lasted about (1-3 hours), after which mites stayed quiet. Before molting mites made some successive movement beginning from propodosoma and ending in opisthosoma. The mite tried to free itself from the old exuvium by twisting movement and subsequently withdrew the forelegs and anterior part of the body outside. Newly emerged mites individuals stayed quiet near their old skin for a short period, and then started to move activity searching for their preys.

\section{Mating:}

Both $L$. aegypticus males and females accepted copulation immediately after emergence. Male approached female anteriorly and both vibrated their palps and touched it with forelegs. The male then moved around the female to reach her dorsum. Female could move carrying male over her back. This process lasted 6-10 minutes. After this, male crawled underneath the female and clasped its body with the third and fourth legs, while male and female ventral surfaces were face each other, nearly half body of the male projected behind the female. After copulation, both sexes separated and female accepted mating more than once.

\section{Incubation period:}

Statistical analysis of data presented in Tables (1\&2), indicated that the mean incubation period of egg which gives rise to female and males of $L$. aegypticus differed significantly on different diets and temperatures. The longest incubation period was noticed when the females fed on R. echinopus at $25^{\circ} \mathrm{C}$ (2.2 days), (Table 1); while the shortest was recorded for male individuals fed on R. echinopus at $35^{\circ} \mathrm{C}$, and took 1.57 days (Table 2).The statistical analysis of obtained data showed that ( L.S.D at 0.05 level = 0.551 and 0.078 for effect of diet and temperature on female individuals, respectively, (Table 1) and 0.514 and 0.066 on male, respectively, (Table 2).

\section{Life cycle:}

Data in Tables (1 and 2) showed the effect of different diets on the life cycle of L. aegypticus females and males. It was longer when females reared on A. niger at $25^{\circ} \mathrm{C}$, as 8.15 days, with L.S. D. at 0.05 level $=0.254$ and 0.236 for effect of both diets and temperatures, respectively. Males lasted the shortest period 6.2 days when fed on $A$. siro at $35^{\circ} \mathrm{C}$, with L.S.D. at 0.05 level $=0.244$ and 0.230 for effect of diets and temperatures, respectively.

\section{Pre-oviposition, oviposition and post-oviposition periods:}

The duration of pre-oviposition period of $L$. aegypticus on different diets represented in Table (1), averaged 2.2, 2.1 and 1.8 days when the females fed $R$. echinopus, A. siro and A. niger at $25^{\circ} \mathrm{C}$, respectively. It decreased to $2.0,1.7$ and 1.4 days at $35^{\circ} \mathrm{C}$, respectively.

\section{Longevity:}

Result in table (1) indicated that the mean longevity of $L$. aegypticus female when fed on $R$. echinopus at $25{ }^{\circ} \mathrm{C}$ took the longest period (17.4 days). This period changed to 16.5 and 12.7 days on A. siro and A. niger, at the same temperature. However the female longevity at $35^{\circ} \mathrm{C}$, averaged $15.6,14.3$ and 10.5 days when reared on the same previously mentioned diets, respectively. The longevity of male individuals reached the highest level on 15.8 days at $25^{\circ} \mathrm{C}$ on $R$. echinopus, as decreased on $A$. niger at $35^{\circ} \mathrm{C}$, (durated 8.18 days).

\section{Fecundity:}

The fecundity (number of laid eggs) of L. aegypticus female was affected by diets as shown in Table (1). It was high when mites fed on $R$. echinopus at 35 and $25^{\circ} \mathrm{C}$ ( 25.5 and 22.2 eggs, respectively ) followed by 24.5 and 20.1 eggs on A. siro and 20.5 and 17.6 eggs on A. niger, respectively (L.S.D. at 0.05 for diets $=0.662$ and 0.497 for temperatures).

\section{Lifespan:}

Accordingly, the life span of $L$. aegypticus females and males significantly differed on different diets; prolonged on $R$. echinopus and shortened on A. niger, Tables (1 and 2), (L.S.D. at 0.05 level = 0.412 and 0.384 ) in case of effect of diets and temperatures on life span of females, respectively and 0.0 .358 and 0.364 in case of males, respectively The period was $25.55,24.5$ and $19.9 ; 23.2,21.3$ and 17.3 days when the females fed on $R$. echinopus, A. siro and $A$. niger at 25 and $35^{\circ} \mathrm{C}$, respectively changed to 23.3, 21.9 and $18.5 ; 20.8,18.6$ and 14.487.9 days for males at $35^{\circ} \mathrm{C}$, respectively, (Table 2), with L.S.D. at $0.05=0.358$ and 0.364 for diets and temperatures effect.

\section{Hatchability percentage:}

Concerning hatchability percentage of $L$. aegypticus eggs, (Table 1), statistical analysis using L.S.D. at 0.05 pointed out that the percentage was highly significant on different diets. It was 91.2, 88.9and 76.9; 90.2, 85.7 and $73.65 \%$ 
Table (1): Duration of life cycle and fecundity of Lasioseius aegypticus females fed on different diets at $25,35^{\circ} \mathrm{C}$ and $75 \%$ R.H.

\begin{tabular}{|c|c|c|c|c|c|c|c|c|}
\hline & \multicolumn{3}{|c|}{$25^{\circ} \mathrm{C}$} & \multicolumn{3}{|c|}{$35^{\circ} \mathrm{C}$} & \multicolumn{2}{|c|}{ L.S.D.at 0.05} \\
\hline & A & $\mathrm{B}$ & $\mathrm{C}$ & $\mathrm{A}$ & $\mathrm{B}$ & $\mathrm{C}$ & Diets & Tem. \\
\hline Incubation period & $2.2 \pm 0.34$ & $2.0 \pm 0.23$ & $1.95 \pm 0.19$ & $2.0 \pm 0.22$ & $1.87 \pm 0.2$ & $1.77 \pm 0.2$ & 0.551 & 0.078 \\
\hline Life cycle & $8.15 \pm 0.34$ & $8.0 \pm 0.31$ & $7.2 \pm 0.4$ & $7.6 \pm 0.34$ & $7.0 \pm 2.8$ & $6.8 \pm 3.1$ & 0.254 & 0.236 \\
\hline Preoviposition period & $2.2 \pm 0.18$ & $2.1 \pm 0.24$ & $1.8+0.09$ & $2.0 \pm 0.2$ & $1.7 \pm 0.1$ & $1.4 \pm 0.08$ & 0.065 & 0.707 \\
\hline Oviposition period & $12.7 \pm 0.9$ & $12.4 \pm 0.8$ & $9.3+0.9$ & $11.4 \pm 1.1$ & $11.0 \pm 1.0$ & $7.7 \pm 0.68$ & 0.233 & 0.117 \\
\hline Postoviposition period & $2.5 \pm 0.2$ & $2.0 \pm 0.3$ & $1.6 \pm 0.07$ & $2.2 \pm 0.21$ & $1.6 \pm 0.1$ & $1.4 \pm 0.09$ & 0.118 & 0.065 \\
\hline Longevity & $17.4 \underline{+1.1}$ & $16.5 \pm 1.2$ & $12.7 \pm 0.87$ & $15.6 \pm 0.98$ & $14.3 \pm 0.75$ & $10.5 \pm 0.6$ & 0.259 & 0.232 \\
\hline Life span & $25.55 \pm 2.2$ & $24.5+2.0$ & $19.9 \pm 1.8$ & $23.2 \pm 2.2$ & $21.3 \pm 1.9$ & $17.3 \pm 1.4$ & 0.412 & 0.384 \\
\hline Fecundity & $22.2 \pm 2.5$ & $20.1+1.8$ & $17.6 \pm 1.9$ & $25.5 \pm 2.1$ & $24.5 \pm 2.4$ & $20.5 \pm 1.8$ & 0.662 & 0.497 \\
\hline Hatchability \% & $91.2 \pm 24$ & $88.9 \pm 2.2$ & $76.9 \pm 2.1$ & $90.2 \pm 1.7$ & $85.7 \pm 1.8$ & $73.6 \pm 2.2$ & 0.112 & 0.124 \\
\hline
\end{tabular}

$\mathrm{A}=$ Rhizoglyphus echinopus $\mathrm{B} .=$ Acarus siro $\quad \mathrm{C}=$ Aspergillus niger \pm S.D.

Table (2): Duration of developmental stages of Lasioseius aegypticus males fed on different diets at $25,35^{\circ} \mathrm{C}$ and $75 \%$ R.H.

\begin{tabular}{lcccccccc}
\hline \multirow{2}{*}{ Stages } & \multicolumn{3}{c}{$25^{\circ} \mathrm{C}$} & \multicolumn{3}{c}{$35^{\circ} \mathrm{C}$} & \multicolumn{3}{c}{ L.S.D.at 0.05} \\
\cline { 2 - 9 } & $\mathrm{A}$ & $\mathrm{B}$ & $\mathrm{C}$ & $\mathrm{A}$ & $\mathrm{B}$ & $\mathrm{C}$ & Diets & Tem. \\
\hline Incubation period & $1.77 \pm 0.22$ & $1.89 \pm 0.19$ & $2.0 \pm 0.31$ & $1.57 \pm 0.25$ & $1.66 \pm 0.30$ & $1.88 \pm 0.24$ & 0.514 & 0.066 \\
\hline Life cycle & $7.5 \pm 0.34$ & $7.0 \pm 0.31$ & $7.1 \pm 0.44$ & $6.9 \pm 0.34$ & $6.2 \pm 2.8$ & $6.3 \pm 3.12$ & 0.244 & 0.230 \\
\hline Longevity & $15.8 \pm 10.85$ & $14.9 \pm 1.2$ & $11.4 \pm 0.87$ & $13.9 \pm 0.98$ & $12.4 \pm 0.75$ & $8.18 \pm 0.6$ & 0.224 & 0.209 \\
\hline Life span & $23.3 \pm 1.7$ & $21.9 \pm 2.1$ & $18.5 \pm 1.8$ & $20.8 \pm 2.0$ & $18.6 \pm 2.1$ & $14.48 \pm 1.9$ & 0.358 & 0.364 \\
\hline
\end{tabular}

$\mathrm{A}=$ Rhizoglyphus echinopus $\mathrm{B}=$ Acarus siro $\mathrm{C}=$ Aspergillus niger $\quad \pm \mathrm{S} . \mathrm{D}$.

when the mite females fed on $R$. echinopus, A. siro and A. niger at 25 and $35^{\circ} \mathrm{C}$, respectively. The statistical analysis of obtained data showed that L.S.D. at. 0.05 level $=0.112$ and 0.124 for effect of both diets ad temperatures on female eggs hatchability percentages.

These findings are in accordance with the fact that the bulb mite, $R$. echinopus is generally the most important and most frequent stored product mite on stored onion bulbs (Sandhu 1976; Smirnov and Smirnova 1978; Lee and Wen 1980; Gerson et al., 1985 and Gerson et al., 1991). Afifi (1985) reared a new mite species, L. aegypticus which was associated with debris, humus and organic manure. This species proved to be fungivorous; it was fed on $F$. oxysporium and Penicillium viride. Incubation period averaged 2.3 days at $25^{\circ} \mathrm{C}$. Duration of female immature stages averaged 6.6 and 7.5 days, adult longevity averaged 29.8 and 25.7 days, and the number of deposited eggs/female averaged 22.5 and 16.3 eggs when fed on the aforementioned fungi, respectively. Ali (1990) reared the four mesostigmatids, Sejeius baloghi, Parasitus wahabi, Lasioseius bispinosus and Machrocheles glaber at 30,25 , and $20^{\circ} \mathrm{C}$. The duration of $S$. baloghi female life cycle averaged $16.24,7.54$ and 37.5 days, respectively; while it was 3.6, 12.09 and 22.17 days, respectively, for $P$. wahabi. At the same degrees of temperatures, life cycle of $L$. bispinosus averaged 33.22, 15.67, and 7.6 days, respectively. Also, it was for M. glober 13.8, 5.96, and 4.21 days, respectively. The female life span and reproduction, interims of larvae produced, of the soil-dwelling predatory mite, L. fimetorum Karg fed on mould mites (T. putrescentiae) were investigated by laboratory experiments at $20^{\circ} \mathrm{C}$, as were the mite's consumption of various prey, (Enkegaord and Brodsgaard, 2000). The oviposition period lasted 23.6 days and a total of 19.4 progeny were produced per female. Females lived for 38.6 days. Ezz El-Dein (2003) studied the effect of different diets on the biological aspects of the predaceous mite L. aegypticus especially developmental period, life cycle and the reproductive rate. The diets were $T$. putrescentiae, collembola and free living nematode. The incubation period, life cycle, longevity and life span significantly differed on the rearing diets. Considering the number of eggs deposited by female, it was higher (22.64) on nematode at $25^{\circ} \mathrm{C}$ and 16.9 on nematode at $15^{\circ} \mathrm{C}$. On the other hand, the collembola shortened the number of eggs. It was 8.73 days at $25^{\circ} \mathrm{C}$ and 6.43 eggs at $15^{\circ} \mathrm{C}$.

The current study emphasizes the importance of mites on stored onion bulbs. Information may aid in understanding and preventing losses caused by mite contamination of stored agricultural products.

\section{REFERENCES}

Afifi, A. M. 1985. Lasioseius aegypticus, a new species from Egypt with notes on its biology (Acari: Gamasida). Proc. Egypt's Nat. Conf. Ent., 
(1): $433-461$.

Ali, F. S. 1990. Biological studies and feeding habits of some species of soil mites. M. Sc. Thesis, Cairo Univ., $157 \mathrm{pp}$.

Enkegaard, A. and Brodsgaard, H. F. 2000. Lasioseius fimetorm: A soil- dwelling predator of grass house pests. Biocontrol, 45 (3): $285-293$.

Evans, G. O. 1961. Observation on the chaetotaxy of the legs in the free living Gamasina (Acari: Mesostigmata). Bul. Brit. Mus. (Nat. Hist.) Zool., 10: 275-303.

Evans, G.O. and Sheals, J. G. 1959. Three new mesostigmatic mites associated with rnillipedes in Indonesia. Ent. Ber., 19:107-111.

Ezz El-Dein, S. A. 2003. Studies on some soil predaceous mites associated with some field crops. M. Sc. Thesis, Fac. Sci. Al-Azhar Univ.

Gerson, U; E. Cohen and Capua, S. 1991. Bulb mite, Rhizoglyphus robini (Astigmata: Acaridae) as an experimental animal. Exp. Appl. Acarol., 12: 1-2: 103-110.

Gerson, U.; S. Yathom; S. Capua and Thorens, D. 1985. Rhizoglyphus robini Claparède (Acari: Astigmata: Acaridae) as a soil mite Acarologia, 26(4): 371-380.

Krantz, G. W. and Walter, D. E. 2009. A Manual of Acarology. Texas Tech Univ. Press, 807 pp.

Lee, H. S. and Wen, H. C. 1980. Field investigation of the acarid bulb mites on onion and their control. J. Agric. Res. China, 29(3): 211-218.

Metwally, A. M.; M. Abou-El-Naga and Ibrahim, G. A. 1983. Biological studies on Hypoaspis miles (B.) (Acarina: Laelapidae). Proc. $5^{\text {th }}$ Arab. Pesticide Conf. Tanta Univ., (3): 336 - 346.

Sandhu, G. S. 1976. New record of bulb mite Rhizoglyphus echinopus (F. and R.) from stored onions in India. Sci.Culture, 42(4): 221-222.

Smirnov, K. S. and Smirnova, G. M. 1978. Pests and diseases of onion. Zashchita Rastenii, pp.53. 